\title{
Mai magyar neologizmusok a nyelvi változás folyamatában: elemzési lehetőségek*
}

1. Bevezetés. Jelen tanulmány a nyelvi változás folyamatának e le m z é séh e z kapcsolódik egy, napjaink magyarnyelv-használatában folyamatosan jelen lévő, jól megfigyelhető jelenség: a neologizmusok témakörének funkcionális-kognitív szempontú tárgyalásával.

2. A nyelvhasználók és a nyelvi változás. A neologizmusok rendszerezésében fontos a nyelvi változás és a nyelvhasználók viszonyának figyelembevétele: „A beszélők nem nyelvük fonológiai és grammatikai rendszerének megváltoztatására irányuló szándékkal hoznak létre újításokat. A beszélők azért indulnak ilyen irányba, mert meghatározott társadalmi céljaik vannak beszélőtársaikkal" (CROFT 2000: 59, fordítás és kiemelés tőlem). A nyelvhasználók nyelvi újításai, az általuk létrehozott nyelvi változások nem elszigetelten, hanem erős egymásra hatásban jönnek létre és léteznek: ,,mivel a beszélőközösségek maguk is hálózatok, új célokat érhetnek el [...]. Mind az egyéni, mind a közösségi folyamatok dinamikusak, és s oha nem szünnek meg" (COOPER 1999: 105 , fordítás és kiemelések tőlem). A kommunikációs folyamatban részt vevő felek egy interaktív szituációban vesznek részt, amely ,tágabb közegben a szociális kogníció része" (TOLCSVAI NAGY 2012: 35, vö. BENCZES 2014: 111-112); ilyen módon a kommunikáció során megjelenő nyelvi újítások is beépülhetnek a nyelvhasználók közös nyelvi tudásába. Nyelvi újdonságok létrehozásakor sok esetben a cél nem pusztán egy-egy új entitás vagy új kategória megnevezése, hanem gyakran a figyelem felkeltése, előtérbe helyezés, nyomatékosítás, a megjegyezhetőség elősegítése is (BENCZES 2014: 110-111). Megjelenhetnek kreatív jelenségek, például a játékos szóhasználat, amely a nyelvhasználók megítélésében gyakran a „trendiség”-gel párosul (vö. LEHRER 2003), illetve segítheti a csoporthoz tartozás érzését is: „A játékos és szellemes nyelvhasználat [...] elösegíti a beszédszituációkban résztvevők közötti egyfajta »bajtársiasság« kialakulását, és erősíti az összetartozás érzését” (LONG-GRAESSER 1988: 57, vö. BENCZES 2014: 112).

3. A neologizmus fogalmának definiálása. A neologizmus fogalmának meghatározására sokfajta definíció olvasható a vonatkozó szakirodalomban. A meghatározásokban általában közös, hogy kiemelik a jelenség ú j d o n s á g j e 11 e g é t . Gyakran azonban problematikus annak meghatározása, hogy adott időben pontosan mit nevezünk neologizmusnak, hiszen egy-egy, a kategóriába tartozó nyelvi jelenség újszerünek számíthat egy nyelvhasználó számára, míg lehetséges, hogy

* Jelen tanulmány a Magyar Nyelvtudományi Társaság felolvasó ülésén 2018. április 10-én elhangzott előadás rövidített, írásbeli változata. Köszönettel tartozom LADÁNYI MÁRIÁnak és SIMON GÁBORnak, hogy hasznos lektori megjegyzéseikkel segítették a tanulmány végső formába öntését.

Magyar Nyelv 115. 2019: 21-35. DOI: 10.18349/MagyarNyelv.2019.1.21 
egy másik számára nem az: „A neologizmus fogalmának, mivoltának meghatározása problémát okoz. [...] ezeket a nyelvi jelenségeket nehéz egyetlen, valamenynyit felölelő meghatározásba belesüríteni” (MINYA 2003: 13).

Jelen elemzés funkcionális-kognitív szempontú megközelítésének megfelelően a neologizmus definiálásakor a jelentés- és stílustulajdonítás nyelvhasználófüggő voltára, dinamikusságára és a nyelvhasználói tapasztalatok fontosságára koncentrál. Ezeknek az értelmében az alábbi módon határozza meg a neologizmus fogalmát: a neologizmus olyan nyelvi jelenség, amelynek „egy adott közlő és/ vagy egy adott befogadó adott szituációban előzetes (vagy ilyen hiányában előzetesként értelmezett) tapasztalataihoz, ismereteihez és az ezekből fakadó elvárásaihoz viszonyítva újszerü jelentést és/vagy újszerű stílust tulajdonít. E jelentés- és stílustulajdonítás dinamikus, a fenti változók függvényében ska láris a m ód osulhat egyazon nyelvhasználó esetében is" (SÓLYOM 2014: 19, kiemelések tőlem).

4. Az elemzések elméleti kerete. A neologizmusok elemzése sokféle szempont szerint történhet: grammatikai felépítésük, szemantikai jellemzőik, a befogadóknak a hozzájuk kapcsolódó jelentés- és stílustulajdonítása alapján, illetve az oktatási folyamatban való megjelenésük is vizsgálható, vizsgálandó.

Jelen tanulmány a fenti szempontok közül többet is érvényesít: a bemutatandó példákat grammatikai felépítésük szerint csoportosítja, az elemzések fó tárgya pedig a szemantikai szerkezet, illetve a neologizmusokhoz kapcsolódó nyelvhasználói attitüdök vizsgálata. Az elemzések elsősorban a fogalmi metaforák, metonímiák (LAKOFF-JOHNSON 1980; KÖVECSES 2005, 2015), a fogalmi integráció (FAUCONNIER-TURNER 1998, 2002; SÓLYOM 2014, 2015, 2016), a stílus szociokulturális tényezői (TOLCSVAI NAGY 2005, 2012), illetve a funkcionális szemléletủ nyelvtantanítás lehetőségei (KUGLER 2015) alapján történnek. Mivel a me ntá 1 i s te rek rugalmas, akár egyazon nyelvhasználó esetében is változásra képes alakulatok, jelen tanulmány amellett érvel, hogy a mentális terek és a fogalmi integráció kiválóan alkalmasak a neologizmusok megértési folyamatainak, valamint a befogadásukhoz kapcsolódó nyelvhasználói hozzáállásnak a reprezentálására. Az említett rugalmasságnak köszönhetően a fogalmi integráció adta elméleti keretben ugyanis sok esetben jobban lehet ábrázolni a nyelvhasználói megértési és befogadási folyamatokat, mint a fogalmi metafora vagy metonímia esetében, amelyek rögzítettebb mentálisreprezentáció-párokkal dolgoznak, mint a blending.

5. Az elemzések alapjául szolgáló empirikus adatfelvételek. Az elemzéseket segítik azok a kér dő́í ve s vi z s gálódá s o k, amelyeket a szerző 2006 óta több mint 1500, különböző életkori csoportba tartozó adatközlővel vett fel a neologizmusokkal kapcsolatban. A kérdőívekben időről időre más-más neologizmusok megértésével, használatával, oktatásával kapcsolatos kérdések jelennek meg. A korábbi években felvett adatok szerves folytatásaként jelennek meg jelen tanulmányban a 2018 tavaszán felvett kérdőíves felmérés ez idáig feldolgozott kérdőíveinek egyes vonatkozó eredményei. 


\section{Az elemzések menete; a tanulmányban elemzendő neologizmusok cso-}

portjai. Jelen tanulmány a neologizmusok grammatikai jellemzői alapján kialakított csoportokban mutat be tipikus példákat, majd egy-egy kiválasztott példa szemantikai-stilisztikai elemzését közli.

6.1. Szófajváltással keletkezett neologizmusok. „Még ha van is néhány történeti bizonyíték a főnév $\rightarrow$ melléknév szófajváltásra [...], az egyetlen különbség a két kategória között eltérő szintaktikai és szemantikai tulajdonságaiknak köszönhetö" (KIEFER 2005: 190, fordítás tőlem). Napjaink magyarnyelv-használatában ugyanakkor gyakran előfordul a szófajváltással keletkezett neologizmusoknak ez a csoportja. Ilyen - régebben, illetve újabban keletkezett - szlenges, laza stílusú szavak például az alap, állat, gáz, király, sirály, zsír mellékneveink. Az utóbbi időben elterjedt közép-, illetve felsőfokú alakjuk is - esetükben ez is a melléknévvé válást bizonyítja. A Magyar Nemzeti Szövegtár 2-ben (a továbbiakban: MNSz2.) $315 \mathrm{db}$ találat volt a király melléknév felsőfokú, $51 \mathrm{db}$ pedig középfokú alakjára (2018 márciusában). Ezeknek a találatoknak a száma nagyobb, mint más, hasonló módon keletkezett magyar neologizmusok (például gáz vagy zsir) esetében a hasonló találatoké. A jelenség feltehetően annak köszönhető, hogy - a többi, felsorolt szóhoz képest - a király régebbi keletkezésủ neologizmus, amelynek metonimikus szófajváltása (vö. pl. UNGERER 2007) révén melléknévi jelentése alakult ki, így közép- és felsőfokú alakjai is begyakorlottabbá, elterjedtebbé váltak már.

6.2. Az alap ('alapvető') melléknév elemzése. A szóban rejlő metaforikusságot - amely a gáz, király, zsír stb. típusú, metonimikus megfeleléseket is tartalmazó neologizmusoktól eltérően egy orientációs metaforának, valamint a 'valamilyen épület alapja' jelentésű fönévvel való közös tulajdonságoknak köszönheti a létrejöttét - a 2014. évi kérdőív kitöltői életkortól függően eltérő mértékben észlelték: míg az általános iskolás korosztály (felső tagozatosok) magyarázataiban egyáltalán nem jelent meg utalás a metaforikusságra, addig a középiskolás tanulók magyarázataikban 51,85\%-ban utaltak rá. Az egyetemi hallgatók, illetve a dolgozó felnőttek azonos arányban, 37,50\%-ban utaltak metaforikusságra. Néhány példa a metaforikusságra utaló válaszokból: „A ház alapja, erre lehet építeni”; „Az alap a házak alapozásával úgy függ össze, hogy innen lehet elkezdeni a munkát, a részletezést”; „Ez az alapja vminek (pl. ház, történet), a mai jelentés meg inkább az alapvető szóból ered".

Amennyiben az alap neologizmus jelentését a fogalmi integrációs modellben elemezzük, ún. egyoldalú hálózatként (vö. KövECSES-BENCZES 2010: 182183) kidolgozódó blendként válik értelmezhetôvé a melléknévi jelentés. Ebben a szerkezetben az alap fónév jelentése kerül párhuzamba a 'kezdetleges, egyszerü', illetve a 'kidolgozható, fejleszthető' jelentésekkel. A generikus térben az „alapszintüség" jellemzői jelennek meg, az integrált térben pedig már az új, melléknévi jelentés elaborálódik: ez a tér tartalmazza az 'egyszerü, kidolgozható, fejleszthetö, a kiinduláshoz szükséges' jelentést.

A leírtak grafikusan az 1. ábrán látható módon ábrázolhatók (vö. SÓLYOM 2016: 196-199): 
1. ábra

Az alap melléknév grafikus ábrázolása blendként

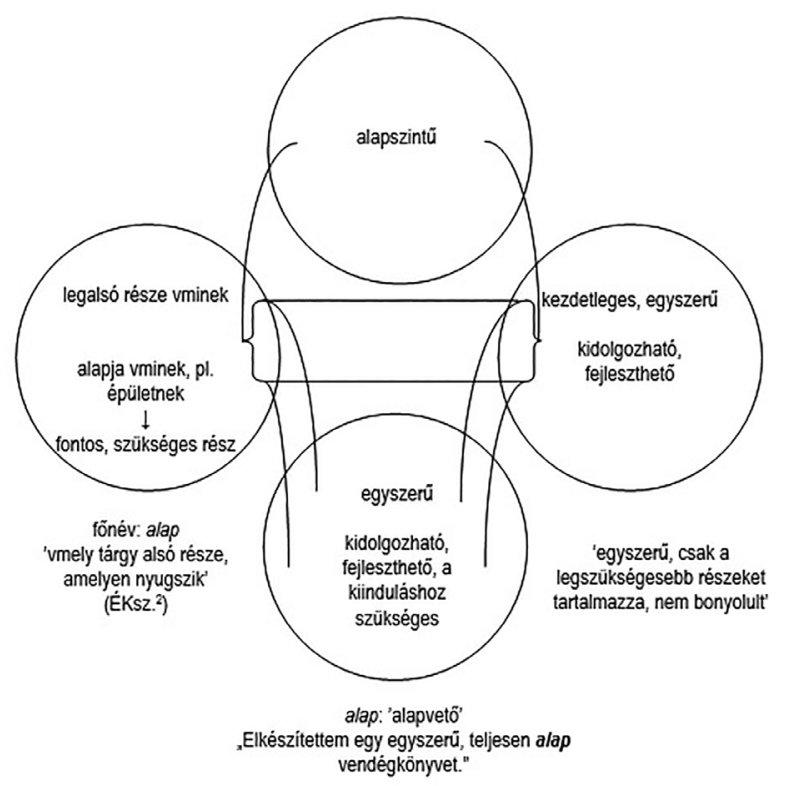

6.3. $-(V) z$ igeképzővel létrejött neologizmusok. A - $(V) z$ igeképző segítségével gyakran jönnek létre a magyar nyelvbe bekerült idegen eredetü főnevekből, illetve ritkábban idegen eredetü tövekből képzett új igék (1. a magyar nyelv korábbi neologizmusait, pl. internetezik, facebookozik, sms-ezik). „A -z denominális verbumképző például a legtöbb jelentésében produktív, például 'az alapszóban megnevezett dologgal végez valamit' (dartsozik, grillez, szaunázik, szoláriumozik, szolizik, tamagocsizik, videózik), 'az alapszóban megnevezett dologgal ellát', 'az alapszóban megnevezett dologgal muzsikál' (szintetizátorozik), 'az alapszóban megnevezett dolgon megy, utazik' (BMX-ezik, gokartozik, mountainbike-ozik, szörföz), 'az alapszóban megnevezett dolgot fogyasztja' (hamburgerezik, heroinozik, marihuánázik, pizzázik), 'az alapszóban megnevezett dologban részt vesz' (aerobikozik, diszkózik, dzsúd(ketchupöz, programoz, tupíroz)ózik, karatézik, tékvandózik) stb." (KESZLER 2000: 309) - olvasható a Magyar grammatikában. H. VARGA MÁRTA megjegyzi: „Minthogy a denominális igéket általában az jellemzi, hogy bennük az általánosabb igefogalom névszói jelentéstartalmú szóhoz (tárgy nevéhez, tulajdonságot jelölő szóhoz stb.) kapcsolódik, a - $(V) z$ és az - $(V) l$ képzők konkrét képzési jelentései is természetesen szoros összefüggésben vannak a képzés alapjául szolgáló névszók jelentésbeli csoportjaival" (H. VARGA 2012: 126). A két igeképző közül a $-(V) z$,túnik produktívabbnak” - állapítja meg LADÁNYI MÁRIA (2007: 107).

Az angol nyelvben a főnév $\rightarrow$ ige szófajváltás esetében a szó alakján sok esetben nem történik változás (pl. knee, nail). A magyarban viszont az igeképzés képző segítségével megy végbe, ezért az angol szótőből képzett igék esetében is megjelenik a képző. Ilyen módon jött létre például a review-z ige. 
A vonatkozó kérdőíves felmérések adatainak alapján megállapítható, hogy a -(V)z képzővel keletkező neologizmusokat könnyen azonosítják a nyelvhasználók. Meg kell jegyezni, hogy az így létrejövő igék szemantikai szerkezete gyakran metonimikus, és a szótőben megnevezett helyre/személyre/csoportra utalnak: az ún. cselekvés IKM-be (idealizált kognitív modellbe) sorolhatók (KÖVECSESBENCZES 2010: 70). Tény ugyanakkor, hogy a létrejövő „eredmény” sok esetben metaforikus lesz, mint azt HEINE, CLAUDI és HÜNNEMEYER grammatikalizációval kapcsolatos jelentésváltozási hipotézise is említi (HEINE-CLAUDI-HÜNNEMEYER 1991: 98-113, vö. LADÁNYI 2007: 99). Így „,a szó szerinti és a metaforikus jelentés közötti köztes jelentés(eke)t tartalmazó mondatokat a kontextus segítségével lehet értelmezni, ill. újraértelmezni” (LADÁNYI 2007: 99-100).

Példák az elmúlt években -(V)z képzővel keletkezett neologizmusokra a gyüjteményből: árnyszínházazik, bezzeg a nyolcvanasévekbenezisjobbvoltozik (sic!), buszsávozik, cigánybünözözik, elbrüsszelezi magát (sic!), fideszezik, garfieldozik, götzézik, habonyozik, ikertornyozik, jegesvödrözik, kormányinfózik, mészároslörincezik, moszkvázik, négerezik, négyesmetrózik, review-z, Soros-maffiázik, szelfizik, szupermenezik. Mint látható, a példák között sok esetben megjelennek a 'valaki(ke)t, valamit (negatív jelentésben) emleget' jelentésủ, mondást, említést kifejező, gyakran ironikus vagy gúnyos stílusú sajtónyelvi és politikai példák - ennek az altípusnak a részletesebb szemantikai elemzését érdemes folytatni a jövőben. ${ }^{1}$

6.4. A szelfizik ('önfényképet készít') elemzése. A magyar ige (szelfizik) létrejöttének érdekessége, hogy az angol kifejezéssel (to take a selfie) szemben egyetlen szóba süríti a leírt jelenséget úgy, hogy a magyarba beillesztett szelfi fönévhez kapcsolódik a - $(V) z$ képző. Nagyon „kompakt” alakulat jön tehát ilyen módon létre, amely a fentebb már említett metonimikusságot, tudniillik azt, hogy a cselekvés (önfénykép készítése) kifejezésére a cselekvés eredményét veszi alapul.

A 2014-ben felvett kérdőíves felmérésben ezzel a szóval kapcsolatban az adatközlők 55,70\%-a adott meg a kikövetkeztethetővel azonos jelentést. 11,39\%uk ugyanakkor metonimikusan tágabban vagy éppen szükebben értelmezte a szót. Ennek az értelmezésnek a következtében születtek például az alábbi jelentésmagyarázatok: „fényképezkedik”, „pózol”, „saját magáról képet csinál, hülye pózban” (sic!) (SólYOM 2015: 93).

A magyar nyelvben a - $(V) z$ képző segítségével létrejövő alakulat jól elemezhető a fogalmi integrációs modellben. A szó szemantikai szerkezete a fogalmi integrációs modellben ábrázolva a két bemeneti tér egyike egy angol eredetü, de már magyar helyesírással írt szótő (szelfi) jelentését ('fénykép saját magáról'), a másik bemeneti tér pedig egy jól ismert, begyakorlott derivációs morfémát, a 'foglalkozik valamivel, készít valamit' jelentésü - $(V) z(i k)$ képzőt tartalmaz. A generikus térben megjelenik a 'saját magáról készít valamit' jelentés, a létrejövő integrált térben pedig a 'fényképet készít saját magáról' jelentés dolgozódik ki.

A leírtak a 2. ábrán látható módon ábrázolhatók grafikusan (az elemzéshez 1. még SóLYOM 2015: 94-et).

${ }^{1}$ Köszönöm LADÁNYI MÁRIÁnak, hogy felhívta a figyelmemet a mondást, említést kifejező igék megjelenésére a gyüjtött neologizmusoknak ebben a csoportjában. 
2. ábra

A szelfizik grafikus ábrázolása blendként

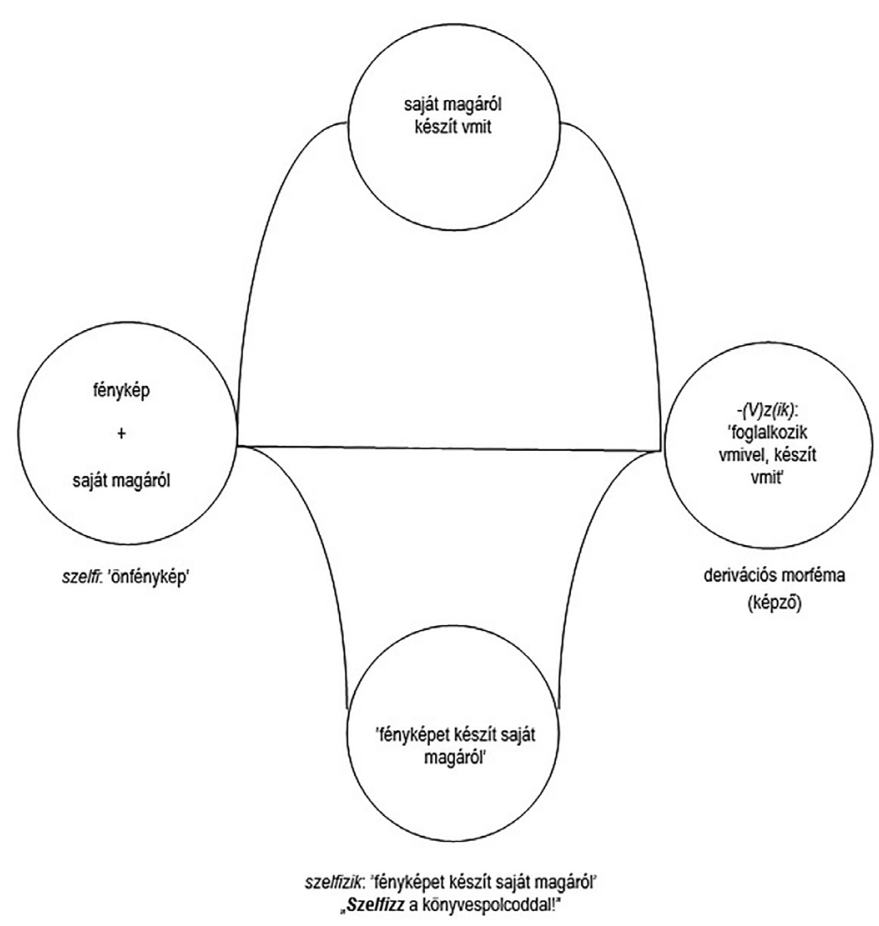

6.5. Elvonással keletkezett neologizmusok. „A magyar nyelvben az utóbbi évtizedekben az elvonásnak gy másik speciális esete terjedt kü1önösen el: amikor összetett fönevekböl összetett igéket hozunk létre oly módon, hogy a fönévi összetételben jelen levő viszonyt érvényesnek tekintjük a belölük elvont összetett igéken belül is, és az így létrejövő összetétel tagjai között olyan szintaktikai viszony alakul ki, amely egyébként nem fordulhat elö: gép + irás > gépirás > gépir; képviselö > képvisel. Létrejöttének mechanizmusa tehát a következő: egyszerü névszó + igéből képzett egyszerü főnév $\rightarrow$ összetett fönév $\rightarrow$ összetett ige" (LENGYEL 2000: 340, kiemelés tőlem).

A fentieket megerösíti, hogy az utóbbi években meglehetősen sok, gyakran laza, kötetlen, néha humoros stílusú neologizmus keletkezett elvonással. A gyüjteményből származó alábbi példák mindegyikére igaz, hogy összetett szóból keletkeztek: árfolyamrögzit, fényfest, kamubejelent, magánrendel, munkamegbeszél. E szavak szemantikai szerkezete könnyen átlátható, amennyiben az eredeti szó (főnév) ismert volt a befogadó számára. Az így létrejövő új szavak ráadásul „gazdaságosak" is, hiszen több tagból álló vagy gyakran csak hosszabb körülírással megadható szerkezetet sürítenek egy szóba.

6.6. Az árfolyamrögzít ('banki hitel árfolyamát rögzíti') elemzése. Ez a neologizmus a 2015. évi kérdőívben szerepelt. Az adatközlők az alábbi, internetről származó mondatot olvashatták a kérdőívben: „Sok devizahiteles »árfolyam- 
rögzít « az AXA Banknál.” Mint látható, az idézetben a neologizmus a szó hapax jellegét hangsúlyozó idézőjelben szerepel.

A kérdőíves válaszokból a szó ritkasága ellenére kiderült, hogy a válaszadók 84,21\%-a helyesen értelmezte a szó jelentését. Ez a fentiekben már említett jelenségre utalhat: a szó szerkezete az összetételi tagok jelentésének ismeretében jól átlátható, föleg akkor, ha az eredeti (fönévi) jelentést, amelyböl elvonással létrejött a neologizmus, ismerte a nyelvhasználó.

Az elvonással létrejövő ige szemantikai szerkezetének ábrázolása a fogalmi integráció keretében a képzéssel tulajdonképpen „ellentétes irányú” folyamatként fogható fel. Ha ábrázolni akarjuk a fogalmi integráció keretében az itt lezajló folyamatot, akkor érdemes először az árfolyamrögzités összetétel szemantikai szerkezetének kialakulását figyelembe venni, vagyis az árfolyam+rögzités szavak által létrehozott blendet ábrázolni. Ebből az integrációból jön ugyanis létre (egyfajta újraelemzéssel, újraértelmezéssel) az árfolyamrögzít+és szerkezet. A nyelvérzék utóbbi esetében a névszóképző „eltávolítása” után a megmaradó alakulatot (árfolyamrögzit) önálló szótőnek érzékelheti, így dolgozódik ki az eredeti blend „szétbontásával”, képzőelvonás útján egy olyan lehetséges bemeneti tér, amely az árfolyamrögzít jellemzőit tartalmazza. A fentiek grafikusan a 3. ábrán látható módon ábrázolhatók.

\section{3. ábra}

Az árfolyamrögzít grafikus ábrázolása blendként

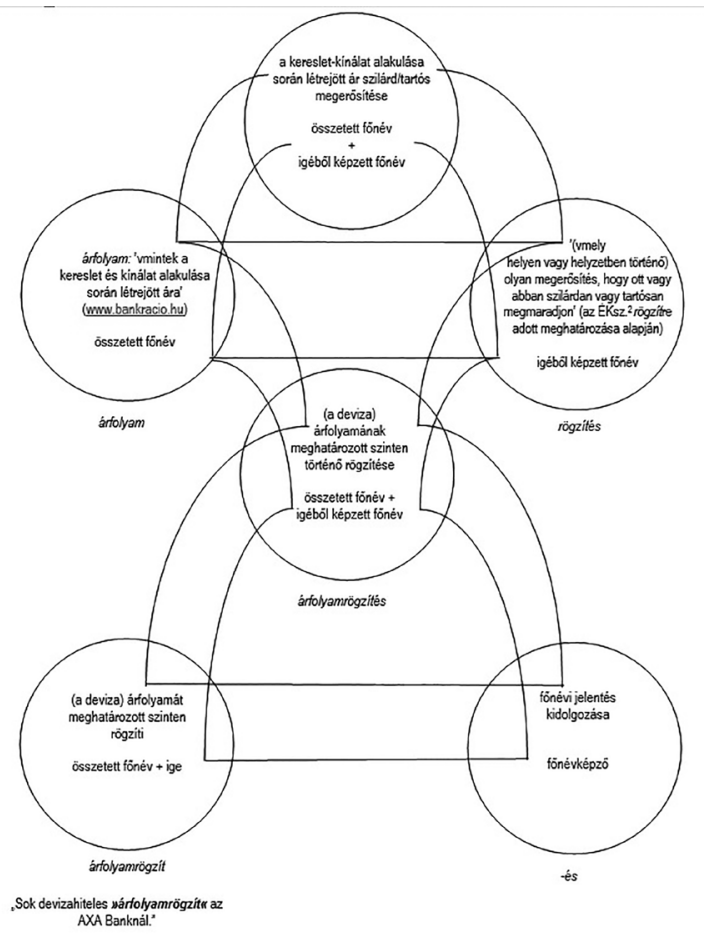


6.7. Be igekötős igék mint neologizmusok. A be igekötő legrégibb magyar igekötőink egyike: „A be igekötő a ki ellentétes jelentésü párja. [...] A be használata azonban korlátozottabb, előfordulása ritkább, funkciói kisebb számúak [...]. Eredeti jelentésétől kevésbé távolodott el, perfektív szerepe aránylag fiatal" - olvashatjuk Az ősi magyar igekötők címü könyvben (J. SolTÉSZ 1959: 107). A fentieknek ellentmond, hogy napjainkban meglehetösen sok be igekötős neologizmus keletkezik, és az egyes alakulatok gyakran több jelentésben, vonzatszerkezetben is élnek egymás mellett.

A be igekötő gyakran megjelenik olyan helyen is, ahol korábban vagy másik igekötő állt, vagy egyáltalán nem volt igekötő. Kérdés, hogy „milyen okokból jönnek létre ezek az alakok: a rendszer szabályainak megfelelő potenciális alakok realizálódásából, puszta szabályszegésből vagy esetleg a rendszer szabályainak átrendeződéséből?" (LADÁNYI 2007: 260). Az esetek nagy részében nem a szabály megszegéséről, hanem az igekötő új helyen, új funkcióban történő használatáról van szó: „A be igekötő új, általánosító szemléletre épülő használata új típusú versengést indíthat el az igekötőrendszeren belül, ill. az igekötők használatában is" (LADÁNYI 2007: 260).

$B e$ igekötös igékre néhány példa a gyüjteményböl: bebont, becéloz, becsalja magát, becsicskul (sic!), bedrágul, beerösit, beesik (a nézettség), begótul (sic!; 'goth stílusúvá válik a megjelenése'), beigér, bejósol, beketyeg, benéz, beprágul (sic!; 'olyanná válik egy város, mint Prága'), bepróbál, berendel, betámad, bevállal.

Be igekötős neologizmusok (bedrágul, beerösit, begótul, bejósol, beketyeg, bekommentel) stílusával kapcsolatban vizsgálódott az a 2016. évi kérdőív, amelyben az adatközlőknek az ilyen módon létrejött neologizmusokhoz kapcsolódó szociokulturális tényezőire (TOLCSVAI NAGY 2005, 2012) kellett reflektálniuk. A kapott eredmények alapján elmondható, hogy az adatközlők föként az érték, a magatartás és a helyzet változójának tekintetében fogalmaztak meg véleményt a kérdéses neologizmusok stílusával kapcsolatban. Természetesen szubjektív véleményekről van szó, ugyanakkor feltünő, hogy az érték dimenziójának vonatkozásában számos, a két ellentétes pólusra - értéktelítő és értékmegvonó - megjegyzés egyaránt megjelent, mégpedig a következő arányban: értékmegvonó jellemzőre utaló véleményt összesen 24 esetben fogalmaztak meg az adatközlők, míg értéktelítő jellemző mindössze 4 válasz esetében jelent meg. Ez a jelenség utalhat a be igekötős neologizmusokkal kapcsolatos attitüdök egymással egészen ellentétes voltára. A magatartással és helyzettel kapcsolatos dimenziók tekintetében látható, hogy az adatközlök érzékelték ezeknek a szavaknak az informális, gyakran szlenges voltát, valamint azt, hogy a felsorolt neologizmusok gyakran tünnek fel az internet, a chat és a fiatalok nyelvében. Elgondolkodtató összefüggés látszik ugyanakkor kirajzolódni a kapott adatokból: a kérdőív eredményeinek tanúsága szerint ugyanis az adatközlők (mint fentebb olvasható, körülbelül hatszoros arányban) inkább helytelenítik ezt a fajta nyelvhasználatot. A kapott válaszokra az 1. táblázat mutat be néhány jellemző példát. 


\section{1. táblázat}

Jellemző példák be igekötős neologizmusok stílusával kapcsolatban kapott adatközlői válaszokra (2016)

\begin{tabular}{|l|l|l|}
\hline \multicolumn{1}{|c|}{ Értéktelítö } & \multicolumn{1}{|c|}{ Értékmegvonó } & \multicolumn{1}{c|}{ Magatartás, helyzet } \\
\hline fiatalos, & feleslegesnek érzem a be igekötőt, & informális, \\
kedves, & pongyola, & szleng(es), \\
vicces, & szerintem nem szép, & közvetlen, \\
frappáns & durvább jelentést ad, & 21. századi internetnyelv, \\
& komolytalan, & chat-nyelv, \\
& idétlen (sic!), & ifúsági nyelv, \\
& "suttyós" (sic!), & közvetlen, \\
& divatos, \\
& & laza, \\
& & kötetlen, \\
& & nem hivatalos \\
\hline
\end{tabular}

6.8. A bejósol ('pontosan megjósol, előre jelez') elemzése. A fent bemutatott be igekötős neologizmusok közé tartozik a bejósol. A szóban megjelenő igekötő funkciójához kapcsolódó kérdésre („Ön szerint mit fejez ki a be igekötő a példamondatban kiemelt szóban?”, ahol az alábbi, internetről származó példamondatot olvashatták az adatközlők: ,a négyéves kor utáni teljesítményt már nem lehet az anya végzettsége alapján bejósolni") a 2016-ban felvett kérdőíves felmérés során az adatközlők válaszai az alábbiak voltak: „Az időbe való betekintés miatt kerülhetett oda”; „Folyamat kezdeményét (sic!) jelöli”; „Beállítani a jóslás eredményét.”; „Lehet, hogy a belátni szóból »ragadt át «”; „Irányultság”; „A beteljesülő jóslatra utal”; „Bekövetkezik miatt alakulhatott ki”; „Jövő időt, a meg helyett".

A fenti válaszok alapján megállapítható, hogy az újonnan megjelenő igekötő (be) egyfelöl analógiásan, más be igekötős igék (bekövetkezik, belát, betekint) mintájára, másfelől metaforikusan (AZ IDŐ TARTÁLY, tehát olyan valami, amelybe bele lehet nézni) utal a jóslás pontosságára, illetve kezdetére. A bejósol szemantikai elemzése a fogalmi integráció keretében a következőképpen alakul: az egyik bemeneti térben a be igekötő által kifejezett befelé irányuló mozgás/cselekvés, a teljesség, valamint a pontosság jelenik meg. A másik bemeneti térben, amely a (meg)jósol igét tartalmazza, szintén megjelenik a teljesség mozzanata, valamint a 'bekövetkezendőnek sejtet, mond' (ÉKsz. ${ }^{2}$ ) és a 'jövőbe lát' jelentés - utóbbi azért fontos, mert előhívja az említett IDŐ TARTÁLY metaforát. A generikus térben ezen a metaforán kívül a '(meg)csinál valamit egy tartályszerủ dolog belsejébe irányulva' jelentés jelenik meg. A blendben az elsőként említett bemeneti térből a pontosság és a teljesség, a másikból pedig a jövőbe látás és (a meg igekötő figyelembevételével) a teljesség képeződik le. Az elmondottak grafikusan a 4. ábrán látható módon ábrázolhatók. 
4. ábra

A bejósol grafikus ábrázolása blendként

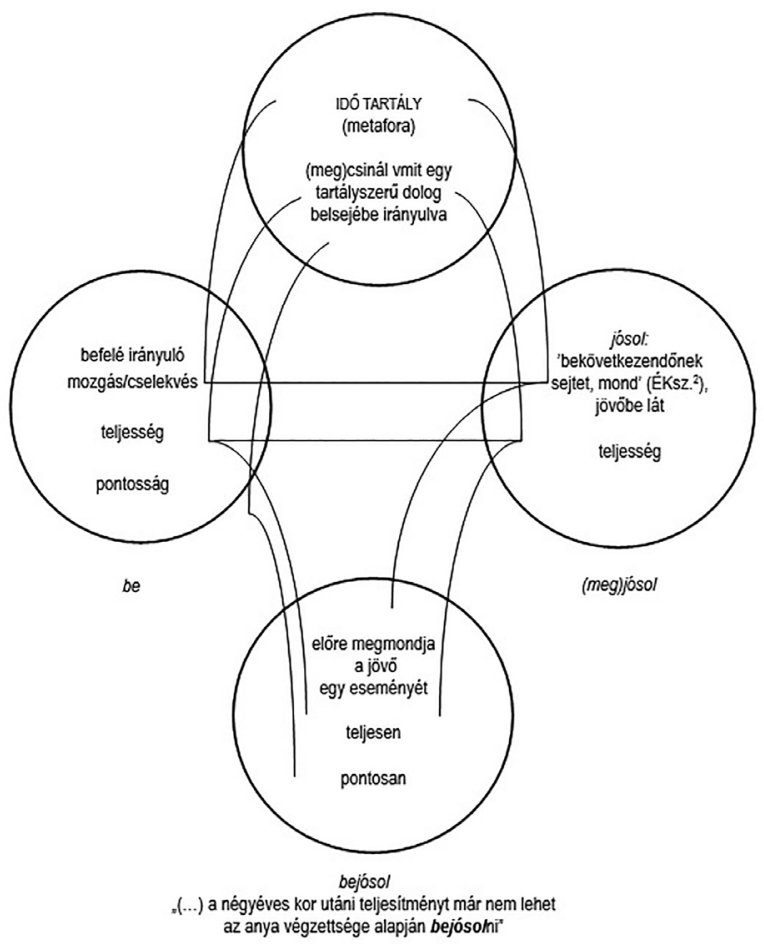

7. A neologizmusok megjelenése az alap- és középfokú oktatásban. A neologizmusok témaköre: létrejöttük, gyüjtési és elemzési módjaik tárgyalása releváns az alap- és középfokú oktatás tananyagainak tekintetében is. A témát összevetve a Nemzeti alaptanterv vonatkozó fejlesztési feladataival ${ }^{2}$, több, a nyelvi változási folyamatokhoz és a neologizmusok megismeréséhez kapcsolódó területet találhatunk, úgymint: a szókincs folyamatos gazdagítása a nyelv minden rétegére kiterjedően (9-12. évfolyam); a nyelv több szempontú megközelítése (a nyelv mint jelrendszer, nyelv és gondolkodás, nyelv és cselekvés, nyelv és kreativitás, nyelvtípusok; 9-12. évfolyam); napjaink nyelvi változásainak felismerése (9-12. évfolyam). A témakörhöz kapcsolódóan két kérdőíves adatfelvétel $(2015,2018)$ is tartalmazott kérdéseket. Az alábbiakban a kapott válaszok rövid bemutatása következik.

8. Két kérdőíves felmérés eredményei a neologizmusok oktatásának vonatkozásában. A 2015. évi kérdőívet diplomával már rendelkező, levelező képzés keretében magyartanár mesterszakos tanárok töltötték ki a Károli Gáspár Refor-

2 110/2012. (VI. 4.) Korm. rendelet A Nemzeti alaptanterv kiadásáról, bevezetéséről és alkalmazásáról. Magyar Közlöny 2012/66: 10635-10847. http://ofi.hu/sites/default/files/attachments/ mk_nat_20121.pdf (2019.02.10.) 
mátus Egyetem Bölcsészettudományi Karán. A 2018 márciusában felvett kérdöívet osztatlan tanár szakra járó, első-, másod- és harmadéves hallgatók töltötték ki, akik az Anyanyelvi ismeretek, illetve az Új szavak, kifejezések szemantikája és stilisztikája címü választható kurzus résztvevői voltak. (A 2018. évi adatfelvétel ezt a felvételt követően még folytatódott, folytatódik további kitöltőkkel, jelen tanulmány a 2018 márciusában kitöltött kérdöívek vonatkozó eredményeit ismerteti.)

A kérdés mindkét évben ugyanaz volt: Mi a véleménye: feltünhetnek-e a kérdőívben megjelölt új szavakhoz hasonló neologizmusok az oktatásban? Kell-e, lehet-e említést tenni róluk a magyarórán? Ha igen, miért és milyen témakörökhöz kapcsolódóan? Ha nem, miért nem? Röviden fejtse ki véleményét!

A már tanári diplomával rendelkező, a gyakorlatban is tanító tanárok egy csoportja kevésbé volt megengedő a neologizmusok használatával kapcsolatban: ők hangot adtak negatív véleményüknek. Ennek következtében a 2015. évi felmérés során alapvetően háromfajta attitüd mutatkozott meg. Az alábbiakban ezek részletezése következik; az egyes csoportokat egy-egy releváns, adatközlőktől származó idézet jellemzi.

1. csoport: kell, hasznos beszélni a neologizmusokról, hiszen a diákok nyelvében nap mint nap feltűnnek ezek. (Pl. „Érdemes említést tenni a tanítási órákon ezekről vagy hasonló szavakról. A tanulónak érdekes is, ha hozzá közelebb álló dolgokról beszélünk.")

2. csoport: a kérdőív bizonyos szavai „,helytelenek”, „hibásak”, semmiképpen nem szabad beszélni róluk magyarórán. (P1. „1-6. kiemelt szavait kerüljük, példaként ne adjuk. Tudjuk, hogy a köznyelvben használják, de irodalmi szövegalkotásnál véleményem szerint nem elfogadhatók. 7-8. - ezek szépirodalmi példák, Lackfi János- és Varró Dániel-idézetek hapaxai: szertefelhöz, szinehagy - jó dolog érdekes új szavakat kitalálni, »alkotni«".) Érdekes ellentmondás volt az idézett vélemény esetében, hogy míg a köznyelvi neologizmusokkal kapcsolatban elítélő volt az adatközlő véleménye, addig a szépirodalmi - költők által létrehozott - újdonságokkal sokkal megengedőbb volt.

3. csoport: érdemes beszélni a neologizmusokról, de meg kell említeni, hogy milyen kommunikációs szituációban alkalmazhatók, alkalmazandók. (Pl. „Mindenképpen célszerü említést tenni róla, hiszen a fiataloknak meg kell tanulniuk, hogy milyen fórumon milyen nyelvi stílust használjanak, használhatnak.”) Mint az idézet is bizonyítja, ez a hozzáállás vette leginkább figyelembe a kommunikációs szituációt, valamint a stílusrétegeket a neologizmushasználat esetében.

A 2018. évi kérdőívet nappali szakra járó, fiatalabb hallgatók töltötték ki. Ennek megfelelően - az eddig értékelt kérdőívek tanúsága szerint - az ő véleményük kevésbé volt elítélö a neologizmusok használatával és oktatásával kapcsolatban. Esetükben tipikusan két attitüd jelent meg (a másik csoportéhoz képest a tiltás nem), de sokkal kevesebben emelték ki a „mikor és miért” funkciót a neologizmushasználattal kapcsolatban. Véleményük a következőképpen alakult (a csoportok után itt is egy-egy jellemző vélemény olvasható):

1. csoport: kell, hasznos beszélni a neologizmusokról, hiszen a diákok nyelvében nap mint nap feltünnek ezek. (Pl. „Persze hogy kell, a fiatalok is folyton alkotnak új szavakat, érdeklik őket az új kifejezések - és fontos, hogy érezzék, ők 
is alakítják a nyelvet, mert ők is beszélők. A neologizmus nem bün (sic!). Irodalom- és nyelvtanórán egyaránt lehet vele foglalkozni.”)

2. csoport: érdemes beszélni a neologizmusokról, de meg kell említeni, hogy milyen kommunikációs szituációban alkalmazhatók, alkalmazandók. (Pl. „Szerintem kell említeni őket a magyarórákon, mert meg kell tanítani őket, hogy milyen szavakat mikor, hol és hogyan lehet használni.")

Összességében megállapítható, hogy gyakorlatban már tanító tanárok válaszainak esetében jelent meg az a vélemény, hogy a vizsgált neologizmusok között találhatók olyanok, amelyeket nem szabad tanítani, mert „helytelenek”. A többi választípus mind ennek a korcsoportnak, mind a fiatalabb, tanárjelölt korcsoportnak az esetében megengedőbb attitüdöt tükröz: vagy kifejezetten támogatja a neologizmusok tárgyalását az oktatás során, vagy javasolja a tanításukat, miközben hangsúlyozza: fel kell hívni a diákok figyelmét a kommunikációs helyzetből fakadó stílusbeli jellegzetességekre, elvárásokra is.

9. Összegzés. Jelen tanulmány az elmúlt években gyüjtött és elemzett, változatos grammatikai és szemantikai felépítésü neologi z mu s o kbó 1 elemzett néhányat. Amellett érvelt, hogy a fogalmi integráció keretében történő elemzés gyümölcsöző különböző grammatikai és szemantikai szerkezetü magyar neologizmusok elemzése esetében. Ezt bizonyítandó, bemutatott négy példát a választott keretben történő elemzésre. A példák elemzése során grafikus ábrákkal is szemléltette, milyen módon zajlik a jelentésképzés és a befogadás folyamata egy-egy neologizmus használatakor. A téma és az elemzések aktualitását támasztották alá annak a két kérdőíves felmérésnek a vonatkozó adatai is, amelyet tanárok és tanárjelöltek adtak meg a neologizmusok tanításával, taníthatóságával kapcsolatban, és amelyek legnagyobbrészt azt bizonyították, hogy fontos és érdekes témát jelenthet a magyar nyelvi órán a neologizmusok témakörének tárgyalása.

Kulcsszók: neologizmus, nyelvi változás, szemantikai-stilisztikai elemzés, metonímia, metafora, fogalmi integráció.

\section{Hivatkozott irodalom}

BENCZES RÉKA 2014. Ami rímel, az stimmel: Az alliteráció és a rím szerepe a neologizmusokban. In: LADÁNYI MÁRIA - VLADÁR ZSUZSA - HRENEK ÉVA szerk., Nyelv, társadalom, kultúra: interkulturális és multikulturális perspektivák I-II. A XXIII. Magyar Alkalmazott Nyelvészeti Kongresszus (ELTE BTK Budapest, 2013. március 26-28.) elöadásaiból készült tanulmánykötet. MANYE - Tinta Könyvkiadó, Budapest. 109-114.

COOPER, DAVID L. 1999. Linguistic Attractors: The Cognitive Dynamics of Language Acquisition and Change. John Benjamins, Amsterdam-Philadelphia.

COUlson, SEANA - OAKLeY, TODD 2003. Metonymy and conceptual blending. In: PANTHER, KLAUS-UwE - THORNBURG, LINDA L. eds., Metonymy and pragmatic inferencing. John Benjamins, Amsterdam-Philadelphia. 51-80. https://doi.org/10.1075/[-] pbns.113.06cou 
Croft, William 2000. Explaining Language Change. An Evolutionary Approach. Longman, Harlow - New York.

Fauconnier, Gilles 1994. Mental Spaces. MIT Press - Cambridge University Press, Cambridge.

FAUCONNIER, GILles - Turner, MARK 1998. Principles of Conceptual Integration. In: Koenig, JeAn-PIERre ed., Discourse and Cognition. CSLI Publications, Stanford. 269-283.

FAuconnier, GiLles - Turner, Mark 2002. The Way We Think. Conceptual Blending and the Mind's Hidden Complexities. Basic Books, New York.

Grady, Joseph E. - OAKLEY, TODD - COUlson, SEANA 1999. Blending and metaphor. In: StEEN, GERARD - GIBBS, RAYMOND eds., Metaphor in cognitive linguistics. John Benjamins, Philadelphia. 101-125. https://doi.org/10.1075/pbns.113.06cou

HeIne, BERND - Claudi, UlRIKE - HÜNNEMEYER, FrIEDERIKE 1991. Grammaticalization: A Conceptual Framework. University of Chicago Press, Chicago.

KELLER, RUDI 1990. Sprachwandel: von der Unsichtbaren Hand in der Sprache. Francke, Tübingen.

Keszler BorbÁla 2000. A szóképzés. In: Keszler BorBÁla szerk., Magyar grammatika. Nemzeti Tankönyvkiadó, Budapest. 307-320.

KIEFER, FEREnC 2005. Conversion in Hungarian. In: PIŃón, CHristopher - SiPTÁR, PÉTER eds., Approaches to Hungarian. Volume Nine. Papers from The Düsseldorf Conference. Akadémiai Kiadó, Budapest. 187-203.

KÖVECSES ZOLTÁN 2005. A metafora. Gyakorlati bevezetés a kognitív metaforaelméletbe. Typotex Kiadó, Budapest.

KövecSeS, Zoltán 2015. Where Metaphors Come From. Reconsidering Context in Metaphor. Oxford University Press, New York. https://oi.org/10.1093/acprof: oso/9780190224868.001.0001

KÖveCSES ZOLTÁN - BenCZES RÉKA 2010. Kognitív nyelvészet. Akadémiai Kiadó, Budapest.

KUGLER NÓRA 2015. Gyakorlatok a magyar nyelvtan funkcionális szemléletü tanításához. Eötvös Loránd Tudományegyetem, Budapest.

LADÁNYI MÁRIA 2007. Produktivitás és analógia a szóképzésben: elvek és esetek. Tinta Könyvkiadó, Budapest.

LAKOFf, GEORgE - JOHnSOn, MARK 1980. Metaphors We Live By. The University of Chicago Press, Chicago-London.

LEHRER, ADrIENNE 2003. Understanding Trendy Neologisms. Rivista di Linguistica 15/2: 369-382.

LENGYEL KLÁRA 2000. Az elvonás. In: KESZLER BorBÁLA szerk., Magyar grammatika. Nemzeti Tankönyvkiadó, Budapest. 340-341.

LONG, DeBra L. - Graesser, ARTHUR C. 1988. Wit and humor in discourse processing. Discourse Processes 11: 35-60. https://doi.org/10.1080/01638538809544690

MiNYA KÁROLY 2003. Mai magyar nyelvújítás - szókészletünk módosulása a neologizmusok tükrében a rendszerváltozástól az ezredfordulóig. Tinta Könyvkiadó, Budapest.

MNSz2. = Magyar Nemzeti Szövegtár 2. Vö. ORAVECZ CSABA - VÁRADI TAMÁS - SASS BÁLINT 2014. The Hungarian Gigaword Corpus. In: Proceedings of LREC 2014. 
J. SoltÉSz KATALIN 1959. Az ösi magyar igekötők (meg, el, ki, be, fel, le). Akadémiai Kiadó, Budapest.

SÓLYOM RÉKA 2014. A mai magyar neologizmusok szemantikája. Nyelvtudományi Értekezések 165. Akadémiai Kiadó, Budapest.

SÓlYOM RÉKA 2015. A csúcsszelfi becéloz - Napjaink „trendi” neologizmusainak szemantikájáról. In: PAPP ÁGNES KLÁRA - SEBÖK MELINDA - ZSÁVOLYA ZOLTÁN szerk., „Európai látószögü magyar”. Nemzet - sors - identitás. Írások a hatvanéves Bertha Zoltán tiszteletére. L'Harmattan Kiadó, Budapest. 83-96.

SÓLYOM RÉKA 2016. Neologizmusok a mai magyarnyelv-használatban: tendenciák és jellemzők. In: KOZMÁCS ISTVÁN - VANČO ILDIKÓ szerk., Standard - nem standard. Variációk egy nyelv változataira. Válogatás a 18. Élönyelvi Konferencia - Nyitra, 2014. szeptember 18-20. - elöadásaiból 1-Antológia Kiadó, Lakitelek. 2: 129-140.

SzATHMÁRI ISTVÁN 2004. Stilisztikai lexikon. Stilisztikai fogalmak magyarázata szépirodalmi példákkal szemléltetve. Tinta Könyvkiadó, Budapest.

Tolcsvai Nagy, GÁBOR 2005. A Cognitive Theory of Style. Peter Lang, Frankfurt am Main.

TOLCSVAI NAGY GÁBOR 2012. A stílus szociokulturális tényezőinek kognitív nyelvészeti megalapozása. In: TÁTRAI SzILÁRD - TOLCSVAI NAGY GÁBOR szerk., A stílus szociokulturális tényezői. Kognitív stilisztikai tanulmányok. ELTE, Budapest. 19-49.

H. VARGA MÁRTA 2012. Formák és funkciók. Morfoszintaktikai eszközök és grammatikai jelentések vizsgálata. KRE BTK - Patrocinium Kiadó, Budapest.

UNGERER, FrIEDRICH 2007. Word-formation. In: GEERAERTS, DIRK - CUYCKENS, HUBERT eds., The Oxford Handbook of Cognitive Linguistics. Oxford University Press, Oxford. 650-675.

\section{Felhasznált források}

De tényleg, meddig van a gyerek mellett a helyünk? 2014. http://divany.hu/poronty/2014/06/29/de_tenyleg_meddig_van_a_gyerek_mellett_a_helyunk (2014.07. 01.)

Elkészítettem egy egyszerü, teljesen alap vendégkönyvet. Hogyan generáljak rá törlés gombot? 2012. https://www.gyakorikerdesek.hu/szamitastechnika programozas_3528858-elkeszitettem-egy-egyszeru-teljesen-alap-vendegkonyvethogyan-generaljak-ra-to (2013. 03. 23.)

JAK Shelfie. http://jakshelfie.tumblr.com (2014. 01. 28.)

Sok devizahiteles ,árfolyamrögzít” az AXA Banknál - Miért? 2012. https:/www. portfolio.hu/finanszirozas/bankok/sok-devizahiteles-arfolyamrogzit-az-axabanknal-miert.175381.html (2018. 03. 05.)

\section{Current Hungarian neologisms in the process of linguistic change: possibilities of analysis}

The present paper analyses the semantic and stylistic makeup of current Hungarian neologisms in the process of linguistic change, in a functional-cognitive framework. The aim of the analyses is (i) to present case studies of the possibility of a semantic and stylistic analysis of neologisms 
of diverse grammatical structures based on examples collected by the author; (ii) to explore the possibilities of presenting linguistic change in general and neologisms in particular in the process of education, and (iii) to give examples of the mental processes that language users exhibit while using neologisms, taken from relevant data gleaned from questionnaires administered in a number of different years, and in organic unity with the analyses offered previously. The paper illustrates the analyses by graphical representations in terms of the theory of conceptual integration (blending). The content of mental spaces as represented in the figures is determined on the basis of participants' answers in the questionnaire studies.

Keywords: neologism, linguistic change, semantic-stylistic analysis, metonymy, metaphor, conceptual integration.

SÓLYOM RÉKA

Károli Gáspár Református Egyetem 